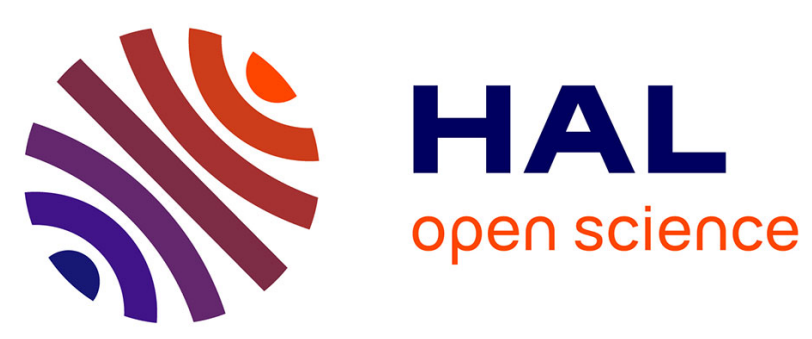

\title{
Modeling ozone and carbon monoxide redistribution by shallow convection over the Amazonian rain forest
}

\author{
J. Edy, S. Cautenet, P. Brémaud
}

\section{To cite this version:}

J. Edy, S. Cautenet, P. Brémaud. Modeling ozone and carbon monoxide redistribution by shallow convection over the Amazonian rain forest. Journal of Geophysical Research: Atmospheres, 1996, 101 (D22), pp.28671-28681. hal-02025355

\section{HAL Id: hal-02025355 \\ https://hal.uca.fr/hal-02025355}

Submitted on 6 Feb 2021

HAL is a multi-disciplinary open access archive for the deposit and dissemination of scientific research documents, whether they are published or not. The documents may come from teaching and research institutions in France or abroad, or from public or private research centers.
L'archive ouverte pluridisciplinaire HAL, est destinée au dépôt et à la diffusion de documents scientifiques de niveau recherche, publiés ou non, émanant des établissements d'enseignement et de recherche français ou étrangers, des laboratoires publics ou privés. 


\title{
Modeling ozone and carbon monoxide redistribution by shallow convection over the Amazonian rain forest
}

\author{
J. Edy and S. Cautenet \\ Laboratoire de Meteorologie Physique, Universite Blaise Pascal, CNRS, Aubiere, France \\ P. Brémaud \\ Laboratoire de Physique Atmosphere, Universite de l'ile de la Reunion, St. Denis, France
}

\begin{abstract}
During a "locally occurring system" (LOS) in Amazonian forest characterized by an active mixing layer from surface to $1000 \mathrm{~m}$ capped by a fossil mixed layer between 1000 and $1500 \mathrm{~m}$, the vertical mixing effects of a shallow cumulus are examined. The explicit redistribution of $\mathrm{CO}$ and $\mathrm{O}_{3}$ has been studied with a two-dimensional convective cloud model coupled with a chemical model including gas and aqueous phases, for a shallow convective situation taken from the GTE/ABLE 2B campaign. The chemistry describes the main oxidation chains of $\mathrm{CH}_{4}$ and $\mathrm{CO}$ in presence of low $\mathrm{NO}_{x}$ concentration in a remote troposphere. Model results compare favorably with observations obtained after development of the shallow convection. The analysis of results explains how a growing and decaying cloud field allows exchanges between a mixing layer, a fossil mixed layer and the free troposphere. An inert tracer study has shown that the layer lying between surface to $500 \mathrm{~m}$ is transported up to $2000 \mathrm{~m}$. Even small clouds are responsible for the transport and the transformation of chemical species. Sensitivity tests are performed to evaluate the relative importance of dynamical, microphysical and chemical processes. The cumulus venting is the main process which modifies the trace species redistribution. The $\mathrm{O}_{3}$ and $\mathrm{CO}$ amounts which are transported by a fair-weather cumulus through the boundary layer and free troposphere in the wet season, over a tropical rain forest, are respectively $1.2 \times 10^{23}$ molecules $\mathrm{km}^{-2} \mathrm{~h}^{-1}$ and $7.7 \times 10^{23}$ molecules km $^{-2}$ $\mathrm{h}^{-1}$. In tropical regions, over rain forest, even with low $\mathrm{NO}_{x}$ concentration, several cumulus exist every day and the vertical fluxes of some chemical species (like $\mathrm{O}_{3}$ ) cannot be neglected.
\end{abstract}

\section{Introduction}

The impact of clouds on the transfer of trace species from boundary layer to the free troposphere is very important in both cases of shallow and deep convection. In tropospheric chemistry, three processes are modified by the presence of clouds: the transport of chemical species, the photochemistry and the aqueous phase chemistry. Several authors have demonstrated that convective clouds constitute a mechanism for intense vertical transport, through observations [Ching et al., 1986; Gidel, 1983; Garstang et al., 1988; Lyons et al., 1986] or through inert tracers modeling [Lafore and Moncrieff, 1989; Pickering et al., 1990; Chaumerliac et al., 1989; Renard et al., 1994].

Clouds have not only the potential to transport chemical species from the mixed layer to the overlying free troposphere but also clouds can transform and modify many chemical species by aqueous phase chemistry occurring in droplets [Chameides and Davies, 1982; Jacob, 1986].

In evaluating regional $\mathrm{CO}$ and $\mathrm{O}_{3}$ budgets, Thompson et al. [1994] show the important effect of convective transport over the Central United States. They estimate that both shallow cumulus and synoptic scale weather systems are as efficient as deep convection, but they point out that relative $\mathrm{CO}$ and $\mathrm{O}_{3}$ fluxes due to shallow convection and synoptic scale weather

Copyright 1996 by the American Geophysical Union.

Paper number 96JD01867.

0148-0227/96/96JD-01867\$09.00 systems are poorly known. Observations of $\mathrm{O}_{3}$ distribution inside and outside the clouds apparently lead to different $\mathrm{O}_{3}$ evolution, depending on the type of clouds (small cumulus or stratiform clouds) [Preiss et al., 1994].

Detailed simulations of clouds and photochemistry in convective situations have highlighted a great degree of variability in dynamical structure and in trace gases redistribution from one event to another one [Scala et al., 1990; Pickering et al., 1990, 1991; Chatfield and Delany, 1990].

All these studies have been achieved using off-line models, without any aqueous chemistry. They show the dominant role of transport during deep convection. More recently, a convection cloud model, explicitly coupled with a gas/aqueous chemical model [Grégoire et al., 1994] exhibits the role of microphysical processes on the redistribution of chemical species among the aqueous and gas phases. With a similar chemistry model, Lelieveld and Crutzen [1991] show the role of clouds on $\mathrm{O}_{3}$ redistribution. They have estimated that if the air is spending 3 at 4 hours inside the clouds in $\mathrm{NO}_{x}$ poor region, net ozone destruction rates are enhanced by factors ranging from 1.7 to 3.7 [Graedel and Crutzen, 1993].

The preceding works, however, have no experimental support. In this paper, we intend to compare model results with experimental data. Using a cloud model coupled with a gas/ aqueous chemical model, we examine the role of the aqueous chemistry in shallow convection when vertical velocity and liquid water content are lower than in deep convection. 


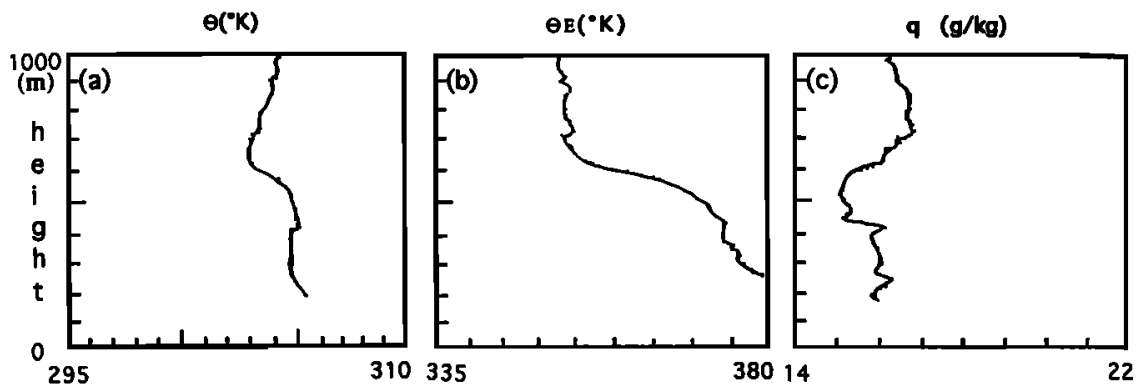

Figure 1. Tethered balloon profile at 1200 local standard time (LST) on May 4, 1987, at Ducke. (a) Potential temperature, (b) equivalent potential temperature, and (c) specific humidity (from $M$. Garstang, personal communication, 1995).

The equatorial forests are an important source of organic acids [Talbot et al., 1990] which can lead to ozone destruction by aqueous chemistry processes. During the GTE/ABLE2B campaign in 1987 (Journal of Geophysical Research, 95, 16,721$17,050,1990$ ) in Amazonia, an observation of a fair cumulus cloud was performed and vertical profiles of $\mathrm{CO}$ and $\mathrm{O}_{3}$ were measured by an instrumented aircraft, the NASA Electra before and after a succession of convective cells developments. Ritter et al. [1990] have examined the influence of such a cloud field on species distributions in the subcloud layer. We use these data to validate our coupled model, and we examine the relative importance of different processes on chemical species distribution due to the presence of small cumulus. Although $\mathrm{O}_{3}$ is a low soluble species, we want to investigate whether the competition between the three governing processes (transport, photochemistry, aqueous chemistry) is important in a case of shallow convection where the vertical velocities are weak but where the liquid water content is not negligible, as in equatorial forest regions.

After a short presentation of experimental data and of the model, we show the comparison between the simulated and observed profiles. Then, sensitivity tests are performed to assess the relative importance of dynamical, microphysical and chemical processes which are competing inside a shallow cumulus.

The case under study represents a local system which includes a fossil mixed layer lying between 1000 and $1500 \mathrm{~m}$ over a tropical rain forest during the wet season. A cumulus penetrates into this layer and destroys it. We examine and evaluate the exchanges between the fossil mixed layer and the mixing layer.

\section{Experimental Data}

\subsection{Meteorological Situation}

The synoptic situation for May 4, 1987, over the central Amazon Basin is consistent with fair-weather conditions, associated with shallow convection and small cumulus. This is typically a so-called "locally occurring system" (LOS), characterized by surface divergence until midafternoon, followed by weak convergence associated with the growing convection [Greco et al., 1990].

The description of the meteorological situation is the following: the $700 \mathrm{hPa}$ streamlines pattern shows a convergence line which lies north-south (NS) along $55^{\circ} \mathrm{W}$ from just north of the equator to about $7.5^{\circ} \mathrm{S}$ with equatorial vortex centred near $54^{\circ} \mathrm{W}$ and $0^{\circ} \mathrm{S}$. Low level flow (5 $\mathrm{m}$ above canopy) at $1120 \mathrm{LST}$ exhibits divergent easterlies across network. A high-pressure center is observed over Tabatinga; another weak high-pressure center lies on the coast at $10^{\circ} \mathrm{S}$, with a ridge between. A NS cloud line is revealed by satellite infrared data at 0900 LST along $55^{\circ} \mathrm{W}$ with center to the north of Belem coast, whereas a clear area extends to the west of Manaus-Tabatinga. Manaus eastward shows the edge of a system along $55^{\circ} \mathrm{W}$. At the 250 $\mathrm{hPa}$ level, flow shows an anticyclone centred near $1.5^{\circ} \mathrm{S}, 52.3^{\circ} \mathrm{W}$ (Amazon mouth) supporting the north/south convergence line. This situation is not likely to undergo rapid changes.

The detailed evolution of the weather from aircraft data is described below:

1. Cloud amounts mainly of fair weather cumulus (CU-1 at 1118 LST) and later (1312 LST) cumulus congestus (CU-2) were present throughout the flight but decreasing in amount from $7 / 8$ sky cover to $4 / 8$ sky cover.

2. Cloud base is ranging between $875 \mathrm{~m}$ at $1138 \mathrm{LST}$ and $1100 \mathrm{~m}$ at $1501 \mathrm{LST}$; cloud top locates between $1625 \mathrm{~m}$ at 1136 LST and $1719 \mathrm{~m}$ at $1501 \mathrm{LST}$.

3. Inversion base ranging between $1250 \mathrm{~m}$ at $1134 \mathrm{LST}$ and $1812 \mathrm{~m}$ at $1320 \mathrm{LST}$.

4. Light showers appeared over the area of operations and were probably present soon after 1300 LST and clearly visible from the aircraft between 1440 and 1457 LST.

On the same day (May 4, 1987), a fair-weather cumulus was studied by Ritter et al. [1990] between 1130 LST and 1440 LST. There were no upper level clouds except isolated patches of cirrus far away. By 1130 LST the convective cloud field became more isolated, and cloud cover decreased to 5/8. By 1440 LST the convective cloud development was over.

\subsection{Thermodynamical Analyses}

This undisturbed day is characterized by a typical mixed layer found above the Amazonian rain forest. The tethered balloon observations and comments which follow have been given by M. Garstang (personal communication, 1995). The tethered balloon observations show a vertical potential temperature profile (Figure 1a) with adiabatic conditions from surface to $1000 \mathrm{~m}$ at $1200 \mathrm{LST}$. Also, the vertical equivalent potential temperature (Figure 1b) and the specific humidity (Figure 1c) profiles look well mixed, although the latter decreases slowly with height over the first $1000 \mathrm{~m}$.

By 1137 LST (Figure 2) a moist adiabatic layer is observed between 1000 and $1200 \mathrm{~m}$, a sharp inversion from 1200 to $1300 \mathrm{~m}$ and a secondary moist adiabatic layer from 1300 to $1600 \mathrm{~m}$. The layer from 1000 to $1800 \mathrm{~m}$ roughly agrees with the vertical extent of cloud. 


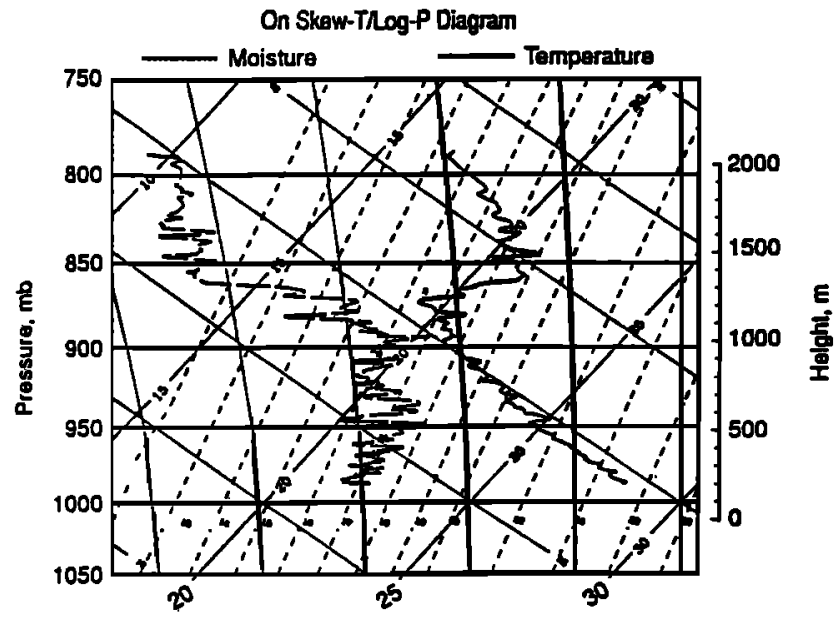

Figure 2. Temperature and moisture profiles obtained during the vertical sounding taken at 1137 LST [from Ritter et al., 1990].

By 1300 LST, gradients are evident in the vertical potential temperature profile (Figure $3 \mathrm{a}$ ), in the vertical equivalent potential temperature profile (Figure $3 b$ ) and in the specific humidity profile (Figure $3 \mathrm{c}$ ). Downdrafts penetrate the mixing layer and a mixing zone exists between the cloud layer and the mixed layer. This is obviously due to the action of precipitation convection. The depth of the mixed layer has now descended to about $500 \mathrm{~m}$ suggesting downward mixing from the cloud layer penetrating to this level.

By 1344 LST we observe (Figure 4) that the inversion zone (from 1400 to $1500 \mathrm{~m}$ ) has weakened and a moist adiabatic layer extents from 1500 to $1700 \mathrm{~m}$.

\subsection{Chemical Data}

Figures 5 and 6 represent the $\mathrm{CO}$ and $\mathrm{O}_{3}$ profiles for the two soundings: 1137 and $1344 \mathrm{LST}$. They both show that $\mathrm{O}_{3}$ concentration increases with height, while $\mathrm{CO}$ concentration decreases. Negative correlation between $\mathrm{CO}$ and $\mathrm{O}_{3}$ in the lower troposphere reflects a sink for $\mathrm{O}_{3}$ at the surface and a source for CO [Harris et al., 1990]. With low (8 ppt) NO concentration (Table 1) there is no $\mathrm{O}_{3}$ production; photochemistry represents a weak sink for $\mathrm{O}_{3}[$ Jacob and Wofsy, 1990; Scala et al., 1990].

For $\mathrm{O}_{3}$ we observe (Figure 5) two mixed layers with constant values: the first below $1000 \mathrm{~m}$ where $\mathrm{O}_{3}$ concentration is 12 ppbv and the second above $1400 \mathrm{~m}$ where $\mathrm{O}_{3}$ concentration is
$20 \mathrm{ppbv}$, which is about twice the values observed near the ground. Between these two mixed layers exists a strong positive gradient of $10 \mathrm{ppbv} \mathrm{km}^{-1}$ from 1000 to $1200 \mathrm{~m}$ and of $30 \mathrm{ppbv}$ $\mathrm{km}^{-1}$ from 1200 to $1400 \mathrm{~m}$ associated to the inversion layer. The lower value of 12 ppbv observed below $1000 \mathrm{~m}$ is explained by deposition during nighttime and in the morning without exchange with the above layers (as the fossil one for instance).

The CO profile (Figure 5) slowly decreases with height below $1000 \mathrm{~m}$. This profile has a different pattern below $1000 \mathrm{~m}$ and above $1000 \mathrm{~m}$, and we observe, as for $\mathrm{O}_{3}$ profile, that during nighttime and the morning there is no exchange with the above layers. Moreover, above $1000 \mathrm{~m}$ a sharp negative $\mathrm{CO}$ gradient exists from 1000 to $1200 \mathrm{~m}$ with a minimum of 105 ppbv at $1200 \mathrm{~m}$. Then, above $1400 \mathrm{~m}$ we see strong alternate positive or negative gradients.

The initial profiles (Figure 5) are consistent with a well established mixed layer (from surface to $800 \mathrm{~m}$ ) and a shallow cloud convective layer between approximately 900 and $1700 \mathrm{~m}$. Enhanced $\mathrm{O}_{3}$ content in and above this cloud layer (1000 to above $2000 \mathrm{~m}$ ) and regions of relatively high CO content (such as the layer near $1500 \mathrm{~m}$ ) are associated with the previous day's fossil mixed layer and with layer structures due to inversions in the subsidence synoptic scale environment. Frequently, fossil mixed layers over Amazonian rain forest [Martin et al., 1988] are observed, generally during undisturbed days. In this case, the boundary layer at $1137 \mathrm{LST}$, is characterized by an active

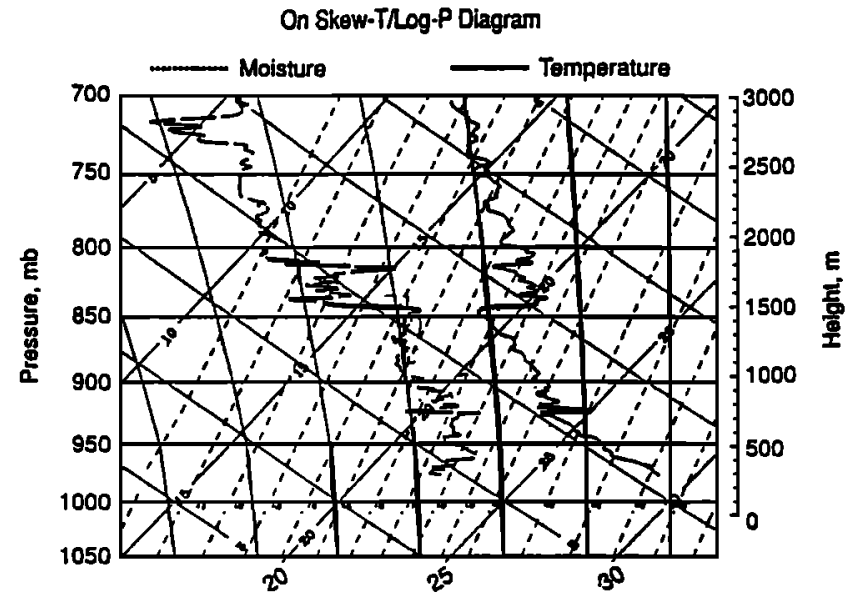

Figure 4. Temperature and moisture profiles obtained during the vertical sounding taken at 1344 LST [from Ritter et al., $1990]$.

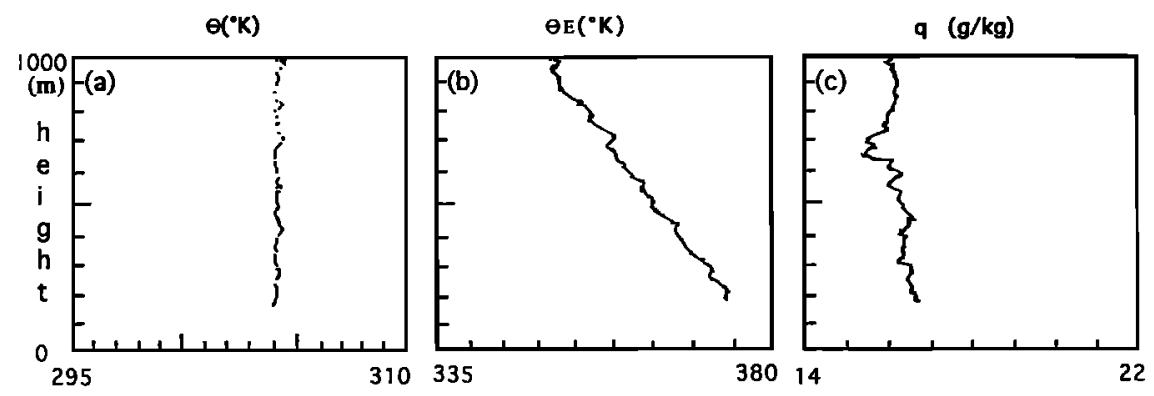

Figure 3. Tethered balloon profile at 1300 LST on May 4, 1987, at Ducke. (a) Potential temperature, (b) equivalent potential temperature, and (c) specific humidity (from M. Garstang, personal communication, 1995). 


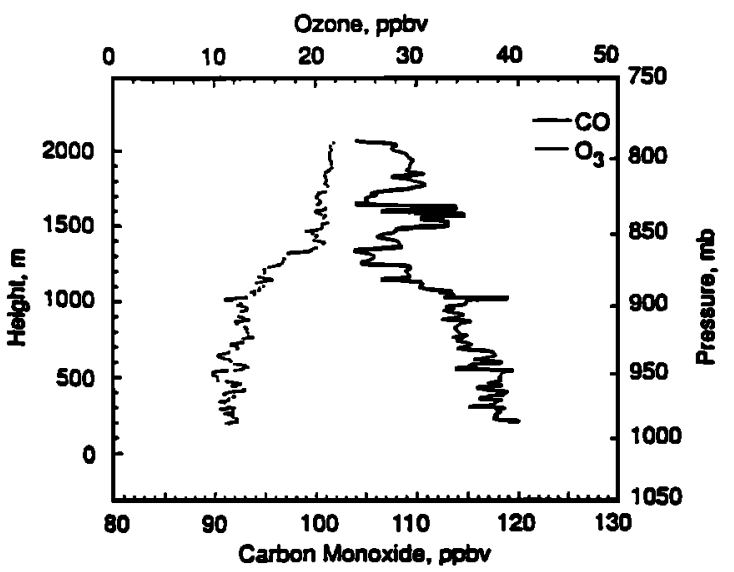

Figure 5. $\mathrm{O}_{3}$ (dashed line) and $\mathrm{CO}$ (solid line) species mixing ratio profiles obtained during the initial sounding of Figure 1 [from Ritter et al., 1990].

mixing layer from surface to $1000 \mathrm{~m}$ capped by a fossil mixed layer between 1000 and $1500 \mathrm{~m}$, mixed but not mixing.

In Figure 6, after the development of shallow convection, we observe a smoothing in the $\mathrm{O}_{3}$ vertical profile and the gradients are much more homogeneous than in Figure 5. The $\mathrm{CO}$ profile (Figure 6) is less mixed than $\mathrm{O}_{3}$ and has a similar shape than the water vapor profile. This pattern may be explained because the $\mathrm{CO}$ source is the ground surface. Figure 6 profiles exhibit the clear signature of a precipitating cumulus which mixes both layers (fossil and underlying mixing layer).

In the case of $\mathrm{O}_{3}$, higher cloud layer values of $\mathrm{O}_{3}$ have been mixed downward into the mixed layer and lower mixed layer values elevated into the cloud layer. In the case of $\mathrm{CO}$, high values prevail near surface (below $750 \mathrm{~m}$ ), but a general decrease with cloud/precipitation mixing has occurred above $750 \mathrm{~m}$. The stratified and layered nature is evident.

\section{Description of the Chemical Transport Cloud Model}

The chemical model [Grégoire et al., 1994] is coupled with a convection model. It monitors 12 chemical species in gaseous and aqueous phases as introduced by Lelieveld and Crutzen [1990,

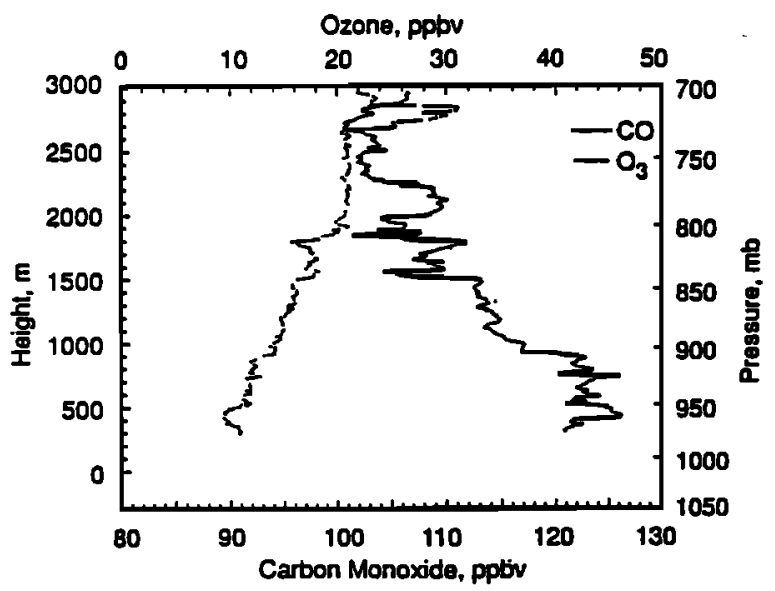

Figure 6. $\mathrm{O}_{3}$ (dashed line) and $\mathrm{CO}$ (solid line) species mixing ratio profiles obtained during the sounding of Figure 4 [from Ritter et al., 1990].
1991]. It describes the main oxidation chains of $\mathrm{CH}_{4}$ and $\mathrm{CO}$ in presence of $\mathrm{NO}_{x}$ in a remote troposphere. Its kinetic scheme presented in Table 2 contains 26 reactions and equilibrium in the gas phase, 16 gas/aqueous phase equilibrium, and 11 aqueous phase reactions. The rate of reaction $\mathrm{G} 4$ has been modified, following Stockwell [1994], to account for its dependency on water vapor and temperature, a feature which was neglected by $L e$ lieveld and Crutzen [1991] and also by Grégoire et al. [1994]. The photolysis rates calculated according to Madronich [1987] for local conditions are assumed constant with time, but may vary with the altitude and the location of the cloud layers. The complete chemical scheme then leads to a set of two primary equations which express the rate of concentration changes between gas and aqueous phases, including mass transfer considerations. Those equations are solved by the Hesstvedt [1978] solver with a time step of $0.5 \mathrm{~s}$ when cloud is present, and a time step of $15 \mathrm{~s}$ otherwise. For more details, the reader is referred to Grégoire et al. [1994].

The cloud model is a two-dimensional $(x, z)$, timedependent, Eulerian scheme [Cautenet and Lefeivre, 1994]. It is nonhydrostatic and anelastic. Three bulk water categories are considered here: vapor, cloud water and rain water. These hydrometeors interact through a variety of physical processes (e.g., condensation, evaporation, autoconversion, coalescence, accretion, and collection). The basic assumptions in the microphysical processes used are (1) a monodisperse, time invariant cloud droplet population in which the total number of droplets is fixed; (2) droplet coalescence (autoconversion) computed using the Kessler [1969] formulation with a threshold; and (3) rain distribution following Marshall and Palmer's [1948] distribution. Surface energy fluxes are prescribed which allow triggering and maintenance of cloud cycles. The horizontal spatial grid resolution is $200 \mathrm{~m}$. The vertical spatial grid resolution is $100 \mathrm{~m}$ in order to be able to describe a fine structure of thermodynamic profile commonly observed within shallow cloud layers. The overall dimension of the modeled domain is $3.2 \mathrm{~km}$ in the vertical and $6.4 \mathrm{~km}$ in the horizontal. The time step of integration is $15 \mathrm{~s}$. The duration of the simulation is 2 hours.

We initialize the model with the atmospheric sounding (Figure 2) along with $\mathrm{O}_{3}$ and $\mathrm{CO}$ profiles (Figure 5) at 1137 LST. For the other species, we take vertically homogeneous profiles in ppb (Table 1), according to Jacob and Wofsy [1990] and Singh et al. [1990]. The $p \mathrm{H}$ is held constant and equal to 5, a typical value of precipitation acidity during ABLE 2B campaign [Jacob and Wofsy, 1990].

The ground budget is prescribed as follows [Fitzjarrald et al., 1990]: the net radiative flux at the beginning of the simulation

Table 1. Initial Values of Chemical Species in the Gas Phase That Are Used to Initialize the Chemical Module

\begin{tabular}{lc}
\hline Chemical Species & Concentrations \\
\hline $\mathrm{O} 3$ & from the sounding \\
$\mathrm{H} 2 \mathrm{O} 2$ & 2.5 parts per billion (ppb) \\
$\mathrm{CH} 3 \mathrm{OOH}$ & $2.0 \mathrm{ppb}$ \\
$\mathrm{CH} 2 \mathrm{O}$ & $0.5 \mathrm{ppb}$ \\
$\mathrm{CO}$ & from the sounding \\
$\mathrm{HNO} 3$ & $0.2 \mathrm{ppb}$ \\
$\mathrm{HO} 2$ & 8.8 parts per trillion (ppt) \\
$\mathrm{OH}$ & $0.08 \mathrm{ppt}$ \\
$\mathrm{NO} 2$ & $12.0 \mathrm{ppt}$ \\
$\mathrm{NO}$ & $8.0 \mathrm{ppt}$ \\
$\mathrm{CH} 3 \mathrm{OO}$ & $4.95 \mathrm{ppt}$ \\
$\mathrm{HCOOH}$ & $0.3 \mathrm{ppb}$ \\
\hline
\end{tabular}


Table 2. List of Reactions With Their Corresponding Rate Constants for Gas Phase, Gas-Aqueos Phase and Aqueous Equilibria, and Aqueous Phase

\begin{tabular}{|c|c|c|}
\hline & Scheme & Rate Constants \\
\hline \multicolumn{3}{|c|}{ Gas Phase Reaction } \\
\hline G1 & $\mathrm{O}_{3}+\mathrm{H}_{2} \mathrm{O}+h \nu \rightarrow 2 \mathrm{OH} \cdot+\mathrm{O}_{2}$ & calculated from Madronich [1987] \\
\hline G2 & $\mathrm{O}_{3}+\mathrm{OH} \cdot \rightarrow \mathrm{HO}_{2} \cdot+\mathrm{O}_{2}$ & $1.6 \times 10^{-12} \exp (-940 / T)$ \\
\hline G3 & $\mathrm{O}_{3}+\mathrm{HO}_{2} \cdot \rightarrow \mathrm{OH} \cdot+2 \mathrm{O}_{2}$ & $1.1 \times 10^{-14} \exp (-500 / T)$ \\
\hline G4 & $2 \mathrm{HO}_{2} \cdot \rightarrow \mathrm{H}_{2} \mathrm{O}_{2}+\mathrm{O}_{2}$ & $\begin{array}{c}\left(2.3 \times 10^{-13} \exp (600 / T)+1.7 \times 10^{-33}[\mathrm{M}] \exp \right. \\
(1000 / T))\left[1+\left(1.4 \times 10^{-21}\right)\left[\mathrm{H}_{2} \mathrm{O}\right] \exp (2200 / T)\right]\end{array}$ \\
\hline G5 & $\mathrm{H}_{2} \mathrm{O}_{2}+h \nu \rightarrow 2 \mathrm{OH} \cdot$ & calculated from Madronich [1987] \\
\hline G6 & $\mathrm{H}_{2} \mathrm{O}_{2}+\mathrm{OH} \cdot \rightarrow \mathrm{HO}_{2} \cdot+\mathrm{H}_{2} \mathrm{O}$ & $3.3 \times 10^{-12} \exp (-200 / T)$ \\
\hline G7 & $\mathrm{CH}_{4}+\mathrm{OH} \cdot+\mathrm{O}_{2}+\mathrm{M} \rightarrow \mathrm{CH}_{3} \mathrm{O}_{2} \cdot+\mathrm{H}_{2} \mathrm{O}+\mathrm{M}$ & $2.3 \times 10^{-12} \exp (-1700 / T)$ \\
\hline G8 & $\mathrm{CH}_{3} \mathrm{O}_{2} \cdot+\mathrm{HO}_{2} \cdot \rightarrow \mathrm{CH}_{3} \mathrm{O}_{2} \mathrm{H}+\mathrm{O}_{2}$ & $4.0 \times 10^{-12}$ \\
\hline G9 & $\mathrm{CH}_{3} \mathrm{O}_{2} \mathrm{H}+\mathrm{O}_{2}+h \nu \rightarrow \mathrm{CH}_{2} \mathrm{O}+\mathrm{HO}_{2} \cdot+\mathrm{OH} \cdot$ & calculated from Madronich [1987] \\
\hline G10 & $\mathrm{CH}_{3} \mathrm{O}_{2} \mathrm{H}+\mathrm{OH} \cdot \rightarrow \mathrm{CH}_{3} \mathrm{O}_{2} \cdot+\mathrm{H}_{2} \mathrm{O}$ & $5.6 \times 10^{-12}$ \\
\hline G11 & $\mathrm{CH}_{3} \mathrm{O}_{2} \mathrm{H}+\mathrm{OH} \cdot \rightarrow \mathrm{CH}_{2} \mathrm{O}+\mathrm{OH} \cdot+\mathrm{H}_{2} \mathrm{O}$ & $4.4 \times 10^{-12}$ \\
\hline G12 & $\mathrm{CH}_{2} \mathrm{O}+2 \mathrm{O}_{2}+h \nu \rightarrow \mathrm{CO}+2 \mathrm{HO}_{2}$ & calculated from Madronich [1987] \\
\hline G13 & $\mathrm{CH}_{2} \mathrm{O}+h \nu \rightarrow \mathrm{CO}+\mathrm{H}_{2}$ & calculated from Madronich [1987] \\
\hline G14 & $\mathrm{CH}_{2} \mathrm{O}+\mathrm{OH} \cdot+\mathrm{O}_{2} \rightarrow \mathrm{CO}+\mathrm{HO}_{2} \cdot+\mathrm{H}_{2} \mathrm{O}$ & $1.1 \times 10^{-11}$ \\
\hline G15 & $\mathrm{CO}+\mathrm{OH} \cdot+\mathrm{O}_{2}+\mathrm{M} \rightarrow \mathrm{CO}_{2}+\mathrm{HO}_{2} \cdot+\mathrm{M}$ & $2.4 \times 10^{-13}$ \\
\hline G16 & $\mathrm{NO}+\mathrm{O}_{3} \rightarrow \mathrm{NO}_{2}+\mathrm{O}_{2}$ & $2.0 \times 10^{-12} \exp (-1400 / T)$ \\
\hline G17 & $\mathrm{NO}_{2}+\mathrm{O}_{2}+h \nu \rightarrow \mathrm{NO}+\mathrm{O}_{3}$ & calculated from Madronıch [1987] \\
\hline G18 & $\mathrm{NO}+\mathrm{HO}_{2} \cdot \rightarrow \mathrm{NO}_{2}+\mathrm{OH}$ & $3.7 \times 10^{-12} \exp (240 / T)$ \\
\hline G19 & $\mathrm{NO}+\mathrm{CH}_{3} \mathrm{O}_{2} \cdot+\mathrm{O}_{2} \rightarrow \mathrm{NO}_{2}+\mathrm{CH}_{2} \mathrm{O}+\mathrm{HO}_{2}$. & $4.2 \times 10^{-12} \exp (180 / T)$ \\
\hline G20 & $\mathrm{NO}_{2}+\mathrm{OH} \cdot+\mathrm{M} \rightarrow \mathrm{HNO}_{3}+\mathrm{M}$ & $1.2 \times 10^{-11}$ \\
\hline G21 & $\mathrm{HNO}_{3}+h \nu \rightarrow \mathrm{NO}_{2}+\mathrm{OH}$ & calculated from Madronıch [1987] \\
\hline G22 & $\mathrm{CH}_{2} \mathrm{O}+\mathrm{HO}_{2} \cdot \leftrightarrow \cdot \mathrm{O}_{2} \mathrm{CH}_{2} \mathrm{OH}$ & $6.7 \times 10^{-15}$ \\
\hline G23 & 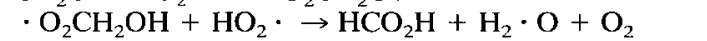 & $2.0 \times 10^{-12}$ \\
\hline G24 & $\cdot \mathrm{O}_{2} \mathrm{CH}_{2} \mathrm{OH}+\mathrm{NO}+\mathrm{O}_{2} \rightarrow \mathrm{HCO}_{2} \mathrm{H}+\mathrm{HO}_{2} \cdot+\mathrm{NO}_{2}$ & $7.0 \times 10^{-12}$ \\
\hline G25 & $2 \cdot \mathrm{O}_{2} \mathrm{CH}_{2} \mathrm{OH}+\mathrm{O}_{2} \rightarrow 2 \mathrm{HCO}_{2} \mathrm{H}+2 \mathrm{HO}_{2}$. & $1.2 \times 10^{-13}$ \\
\hline G26 & $\mathrm{HCO}_{2} \mathrm{H}+\mathrm{OH} \cdot+\mathrm{O}_{2} \rightarrow \mathrm{CO}_{2}+\mathrm{HO}_{2} \cdot+\mathrm{H}_{2} \mathrm{O}$ & $3.2 \times 10^{-13}$ \\
\hline \multicolumn{3}{|c|}{ Gas-Aqueous and Aqueous Phase Equilibria* } \\
\hline E1 & $\mathrm{H}_{2} \mathrm{O} \leftrightarrow \mathrm{H}^{+}+\mathrm{OH}^{-}$ & $1.0 \times 10^{-14} \exp [-6716(1 / T-1 / 298)]$ \\
\hline $\mathrm{H} 1$ & $\mathrm{O}_{3(\mathrm{~g})} \leftrightarrow \mathrm{O}_{3(\mathrm{du})}$ & $1.1 \times 10^{2} \exp [2300(1 / T-1 / 298)]$ \\
\hline $\mathrm{H} 2$ & $\mathrm{H}_{2} \mathrm{O}_{2(\mathrm{~B})} \leftrightarrow \mathrm{H}_{2} \mathrm{O}_{2(\mathrm{aq})}$ & $7.4 \times 10^{4} \operatorname{cxp}[6615(1 / T-1 / 298)]$ \\
\hline E2 & $\mathrm{H}_{2} \mathrm{O}_{2(a \mathrm{u})} \leftrightarrow \mathrm{HO}_{2}^{-}+\mathrm{H}^{+}$ & $2.2 \times 10^{-12} \exp [-3730(1 / T-1 / 298)]$ \\
\hline $\mathrm{H} 3$ & $\mathrm{CH}_{3} \mathrm{O}_{2} \mathrm{H}_{(\mathrm{g})} \leftrightarrow \mathrm{CH}_{3} \mathrm{O}_{2} \mathrm{H}_{(.1 \mathrm{q})}$ & $2.2 \times 10^{-} \exp [5653(1 / T-1 / 298)]$ \\
\hline $\mathrm{H} 4$ & $\mathrm{CH}_{2} \mathrm{O}_{(\mathrm{g})} \stackrel{\leftrightarrow}{\leftrightarrow} \mathrm{CH}_{2}(\mathrm{OH})_{2(1,1)}$ & $2.0 \times 10^{-12} \exp [6425(1 / T-1 / 298)]$ \\
\hline H5 & $\mathrm{HNO}_{3(\mathrm{~g})} \leftrightarrow \mathrm{HNO}_{3(\mathrm{al})}$ & $5.6 \times 10^{-3} \exp [8700(1 / T-1 / 298)]$ \\
\hline E3 & $\mathrm{HNO}_{3(\mathrm{a})} \leftrightarrow \leftrightarrow \mathrm{H}^{+}+\mathrm{NO}_{3}^{-}$ & 15.4 \\
\hline H6 & $\mathrm{HO}_{2} \cdot(\underline{\prime}) \leftrightarrow \mathrm{HO}_{2} \cdot(\mathrm{ay})$ & $2.0 \times 10^{3} \exp [6600(1 / T-1 / 298)]$ \\
\hline E4 & $\mathrm{HO}_{2} \cdot(\mathrm{g}) \mathrm{( \textrm {d } )} \leftrightarrow \mathrm{H}^{+}+\mathrm{O}_{2(\mathrm{dy})}^{-}$ & $3.5 \times 10^{-5}$ \\
\hline $\mathrm{H} 7$ & $\mathrm{OH} \cdot(a) \leftrightarrow \mathrm{OH} \cdot$ & $9.0 \times 10^{3}$ \\
\hline H8 & $\mathrm{NO}_{2(\mathrm{~g})} \leftrightarrow \mathrm{NO}_{2(\mu \mathrm{u})}$ & $6.4 \times 10^{-3} \exp [2500(1 / T-1 / 298)]$ \\
\hline $\mathrm{H} 9$ & $\mathrm{NO}_{(\mathrm{g})}^{2(\mathrm{~g})} \leftrightarrow \mathrm{NO}_{(\mathrm{aq})}^{2(\mathrm{aq})}$ & $1.9 \times 10^{3} \exp [1480(1 / T-1 / 298)]$ \\
\hline $\mathrm{H} 10$ & $\mathrm{CH}_{3} \mathrm{O}_{2} \cdot(\mathrm{g}) \leftrightarrow \mathrm{CH}_{3} \mathrm{O}_{2} \cdot($ (.14) & $2.0 \times 10^{3} \exp [6600(1 / T-1 / 298)]$ \\
\hline $\mathrm{H} 11$ & $\mathrm{HCO}_{2} \mathrm{H}_{(\mathrm{g})} \leftrightarrow \mathrm{HCO}_{2} \mathrm{H}_{(\alpha(\mathrm{c})}$ & $3.7 \times 10^{3} \exp [5700(1 / T-1 / 298)]$ \\
\hline E5 & $\mathrm{HCO}_{2} \mathrm{H}_{(\mathrm{d} 4)} \leftrightarrow \mathrm{H}^{+}+\mathrm{HCO}_{2}^{-}$ & $1.8 \times 10^{4} \exp [-1510(1 / T-1 / 298)]$ \\
\hline \multicolumn{3}{|c|}{ Aqueous Phase Reactuon } \\
\hline A1 & $\mathrm{H}_{2} \mathrm{O}_{2}+h \nu \rightarrow 2 \mathrm{OH}$ & G5 $5 \times 1.6$ \\
\hline A2 & $\mathrm{O}_{3}+h \nu \rightarrow \mathrm{H}_{2} \mathrm{O}_{2}+\mathrm{O}_{2}$ & $\mathrm{G} 1 \times 1.6$ \\
\hline A3 & $\mathrm{CH}_{2}(\mathrm{OH})_{2}+\mathrm{OH} \cdot+\mathrm{O}_{2} \rightarrow \mathrm{HCO}_{2} \mathrm{H}+\mathrm{HO}_{2} \cdot+\mathrm{H}_{2} \mathrm{O}$ & $2.0 \times 10^{\prime} \exp [-1500(1 / T-1 / 298)]$ \\
\hline A4 & $\mathrm{HCO}_{2} \mathrm{H}+\mathrm{OH} \cdot+\mathrm{O}_{2} \rightarrow \mathrm{CO}_{2}+\mathrm{HO}_{2} \cdot+\mathrm{H}_{2} \mathrm{O}$ & $1.6 \times 10^{8} \exp [-1500(1 / T-1 / 298)]$ \\
\hline A5 & $\mathrm{HCO}_{2}^{-}+\mathrm{OH} \cdot+\mathrm{O}_{2} \rightarrow \mathrm{CO}_{2}^{-}+\mathrm{HO}_{2}^{-}+\mathrm{OH}^{-}$ & $2.5 \times 10^{4} \exp [-1500(1 / T-1 / 298)]$ \\
\hline A6 & $\mathrm{O}_{3}+\mathrm{O}_{2}^{-}+\mathrm{H}_{2} \mathrm{O} \rightarrow \mathrm{OH} \cdot+\mathrm{OH}^{-}+2 \mathrm{O}_{2}$ & $1.5 \times 10^{4} \exp [-1500(1 / T-1 / 298)]$ \\
\hline A7 & $\mathrm{HO}_{2}+\mathrm{O}_{2}^{-}+\mathrm{H}_{2} \mathrm{O} \rightarrow \mathrm{H}_{2} \mathrm{O}_{2}+\mathrm{OH}^{-}+\mathrm{O}_{2}$ & $1.5 \times 10^{9} \exp [-1500(1 / T-1 / 298)]$ \\
\hline A8 & $\mathrm{H}_{2} \mathrm{O}_{2}+\mathrm{OH} \cdot \rightarrow \mathrm{HO}_{2} \cdot+\mathrm{H}_{2} \mathrm{O}$ & $1.0 \times 10^{8} \exp [-1715(1 / T-1 / 298)]$ \\
\hline A9 & $\mathrm{CH}_{3} \mathrm{O}_{2} \cdot+\mathrm{O}_{2}^{-}+\mathrm{H}_{2} \mathrm{O} \rightarrow \mathrm{CH}_{3} \mathrm{O}_{2} \mathrm{H}+\mathrm{OH}^{-}+\mathrm{O}_{2}$ & $5.0 \times 10^{7} \exp [-1610(1 / T-1 / 298)]$ \\
\hline A10 & $\mathrm{CH}_{3} \mathrm{O}_{2} \mathrm{H}+\mathrm{OH} \cdot \rightarrow \mathrm{CH}_{3} \mathrm{O}_{2} \cdot+\mathrm{H}_{2} \mathrm{O}$ & $2.7 \times 10^{7} \exp [-1715(1 / T-1 / 298)]$ \\
\hline A11 & $\mathrm{CH}_{3} \mathrm{O}_{2} \mathrm{H}+\mathrm{OH} \cdot \rightarrow \mathrm{CH}_{2}(\mathrm{OH})_{2}+\mathrm{OH}$ & $1.9 \times 10^{7} \exp [-1860(1 / T-1 / 298)]$ \\
\hline
\end{tabular}

${ }^{*}$ Rate constants $\mathrm{K}_{298}$.

(on May 4, 1987 at 12 hours) is $450 \mathrm{~W} \mathrm{~m}^{-2}$ and slowly diminishes during the simulation owing to cloud development and decreasing incident radiative solar flux. The sensible heat flux is $100 \mathrm{~W} \mathrm{~m}^{-2}$ and the latent heat flux is $350 \mathrm{~W} \mathrm{~m}^{-2}$ to account for the strong precipitation which had taken place on the previous day, therefore involving a strong evapotranspiration.

The aim of the modeling study is to test the ability of the model to retrieve the observed data (Figures 3 and 4) at 1344 LT. We want to examine and evaluate the exchanges between the lower layer and free troposphere via the mixing and the fossil layers.

\section{Results and Discussion}

\subsection{Meteorological Results}

The cloud field simulated during 2 hours, on May 4, 1987, is characterized by different cells. The domain is small $(6.4 \mathrm{~km})$, 
but the unique cloud, which undergoes various life cycles, is thought to represent a much longer distribution. During the simulation the cloud cell periodically grows and decays over a period of about $140 \mathrm{~min}$, with a top ranging between 1000 and $2000 \mathrm{~m}$ (Figure $7 \mathrm{~g}$ ). Figure 8 displays the growing and decaying cells (shown by the vertical velocity and liquid content evolution's) with about a 10 to 20 -min period.

At the center of the cell convection, the cloud liquid water content has maximum values of about $1.5 \mathrm{~g} \mathrm{~kg}^{-1}$ and maximum vertical velocity of about $4 \mathrm{~m} \mathrm{~s}^{-1}$ (Figure 8 ).

At the start of the cloud development a strong convective movement is organized. After $30 \mathrm{~min}$ the field of vertical motion extends from surface to $2000 \mathrm{~m}$ (Figures $7 \mathrm{a}$ and $7 \mathrm{~b}$ ). Horizontally, the cell disturbs a large zone. The active mixing layer is mixed with the fossil layer. During the maximum development, exchanges exist from surface to cloud top, that is, about the free troposphere. When the cloud cell decreases, the convection zone is located below $1500 \mathrm{~m}$ and extends horizontally over $3 \mathrm{~km}$. The downdrafts are more intense than updrafts (Figures $7 \mathrm{c}$ and $7 \mathrm{~d}$ ). At the end of our simulation the cloud convection is weak, and light showers are observed. A separated evolution between the cloud convection itself and the mixing layer is observed, in the horizontal and vertical wind fields after about $120 \mathrm{~min}$ (Figures $7 \mathrm{e}, 7 \mathrm{f}$, and $7 \mathrm{~g}$ ). There are two convective cells: the first from the ground to $1000 \mathrm{~m}$ and the second from 1300 to $2200 \mathrm{~m}$ where is found a cloud cell.

The observed thermodynamic structure (Figure 4) exhibits a dry adiabatic layer from 400 to $700 \mathrm{~m}$, a thick inversion layer from 1400 to $1600 \mathrm{~m}$ and a moist adiabatic layer from 1600 to $1800 \mathrm{~m}$ which explains the two modeled cells. A cloud cell is connected to the moist adiabatic layer, and a dry convective cell is the counterpart of the dry adiabatic layer. The upper part of cloud allows the venting through free troposphere, since the low part evaporates in boundary layer. The stability is restored in the boundary layer and when the cloud is less supplied by upward water vapor vanishes very quickly. The cloud evaporates and precipitates weak showers and we observe that convection cell is separated in two parts (Figures 7e and $7 f$ ).

\subsection{Species Behavior in the Cloud Center}

Within the cloud, at $1500-\mathrm{m}$ level, at the center of the convective cell, are displayed (Figures 8 and 9) the cloud liquid water content (grams per kilogram), the vertical speed (meters per second), the $\mathrm{O}_{3}$ and $\mathrm{CO}$ concentration normalized by the initial values during $140 \mathrm{~min}$. The liquid water content maximum is associated with vertical speed maximum. The increase in liquid water content is connected to enhanced latent heat release which in turn induces large positive vertical speeds. Conversely, negative vertical velocities are driven by the evaporative decay of liquid water content. In fact, as mentioned above, several cloud cells cycles are described. $\mathrm{CO}$ and $\mathrm{O}_{3}$ concentrations are evolving out of phase e.g. when an increase in $\mathrm{CO}$ concentration is observed, a decrease in $\mathrm{O}_{3}$ concentration occurs in the same time, and conversely. The main source of $\mathrm{CO}$ is at the ground surface and $\mathrm{CO}$ concentration decreases with altitude, while $\mathrm{O}_{3}$ is generated by photochemistry within the boundary layer so that $\mathrm{O}_{3}$ concentration increases with altitude.

\subsection{Comparison Between Modeled and Observed Profiles}

Figure 10 displays a comparison between modeled and measured profiles at the end of cloud convection. There is a stan- dard deviation of about $10 \%$ between the modeled and measured profiles for both $\mathrm{CO}$ and $\mathrm{O}_{3}$. The modeled profiles are more smoothed than experimental ones. In our model we have taken into account the dynamical, microphysical, gas and aqueous chemistry processes but not the uptake by the forest canopy.

During the shallow convection, cumulus cell can mix both layers (fossil and underlying mixing layer) so that the fossil mixed layer is destroyed. For $\mathrm{O}_{3}$ the profile is simply linearized within the cloud as well as below the cloud. The in-cloud smoothing is obviously driven by the vertical speeds which are very high in this zone. For $\mathrm{CO}$ the source is supplied by the rain forest canopy, and its profile is linearized only within the cloud.

When the convection vanishes, in this subcloud layer, two weak cells of convection, in-cloud (moist) and subcloud (dry), are modeled and can explain the different behaviors of $\mathrm{CO}$ and $\mathrm{O}_{3}$ near surface. The strength of dynamical processes decays near the ground surface. The lower cell below $1000 \mathrm{~m}$ is capped by an inversion layer. This features explain the $\mathrm{CO}$ accumulation at $800 \mathrm{~m}$, obvious in the profile (Figure 10).

\subsection{Inert Tracer Study}

A layered tracer scheme is used to investigate the transport efficiency of a shallow convection cloud field. At initial time an inert tracer layer is introduced into the model domain between surface and $500 \mathrm{~m}$. At the end of simulation $(140 \mathrm{~min})$ we see (Figure 11) that the inert tracer has propagated up to $2000 \mathrm{~m}$. Forty percent of the initial concentration reaches $2.0 \mathrm{~km}$ in altitude over $2 \mathrm{~km}$ wide for a $6.4-\mathrm{km}$ simulated domain in the horizontal. The compounds lying near surface can be transported above boundary layer, in the free troposphere by a fair-weather cumulus. Several studies have been performed for deep and organized cloud convection, in particular squall lines in Amazonia. A squall line is divided into two components: convective and stratiform. These two regions contribute to vertical transport [Houze, 1989]. Thirty to fifty percent of the vertical transport is accomplished by the hot towers (convective region), and the remainder is brought about the trailing stratiform region which also participates to transport in the upper troposphere by anvil region [Greco et al., 1994]. Simulated results (tracer 2 [Scala et al., 1990]) for a squall line show that $40 \%$ of initial concentration reaches $3.5 \mathrm{~km}$ over $10 \mathrm{~km}$ wide and only $2.0 \mathrm{~km}$ in altitude over $30 \mathrm{~km}$ wide for $160 \mathrm{~km}$ simulated domain. Therefore, in a squall line, although vertical transport can be observed up to the upper troposphere, a large amount of surface tracer reaches only $2000 \mathrm{~m}$. The squall lines cover large areas, but these meteorological events have a rare occurrence on the overall year. If we examine the lower troposphere where the biogenical emissions take place, the shallow convection plays a role which must be taken into account. It is quite realistic to hypothesize that, even though fairweather cumulus induces weaker vertical fluxes than squall lines, they are more frequent and can contribute to nonnegligible amounts of net vertical transport of some surface trace compounds in lower troposphere (from surface to $2000 \mathrm{~m}$ ).

\subsection{Main Processes Driving the Chemical In-cloud Species Redistribution}

Sensitivity tests have been performed to evaluate the relative importance of different processes (transport, photochemistry or aqueous chemistry) on chemical species distribution due to the presence of small cumulus.

The evolution of $\mathrm{CO}$ and $\mathrm{O}_{3}$ concentration normalized by 


\section{$\mathbf{U} \mathbf{m} / \mathbf{s}$ \\ Time=30 Minutes}
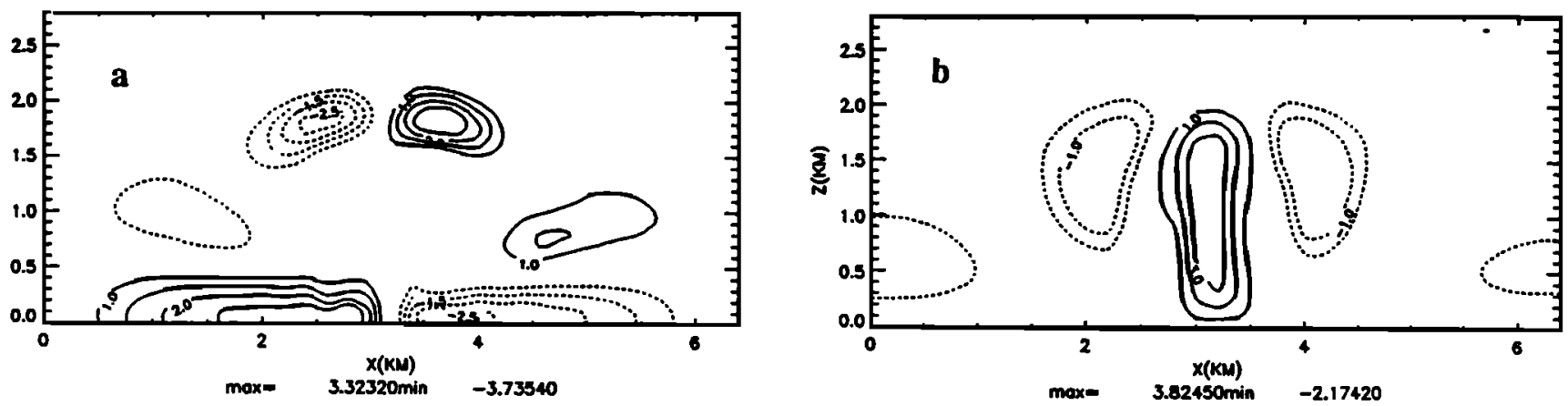

Time $=\mathbf{5 0}$
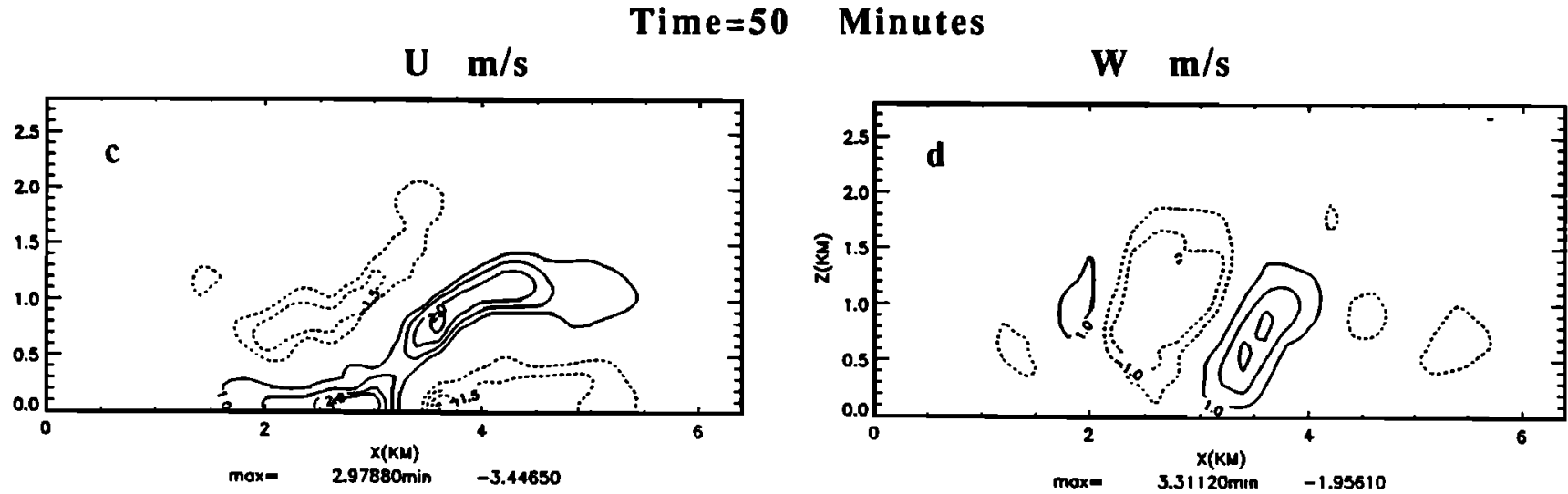

$\operatorname{Time}=120$

$\mathbf{U} \mathbf{m} / \mathbf{s}$

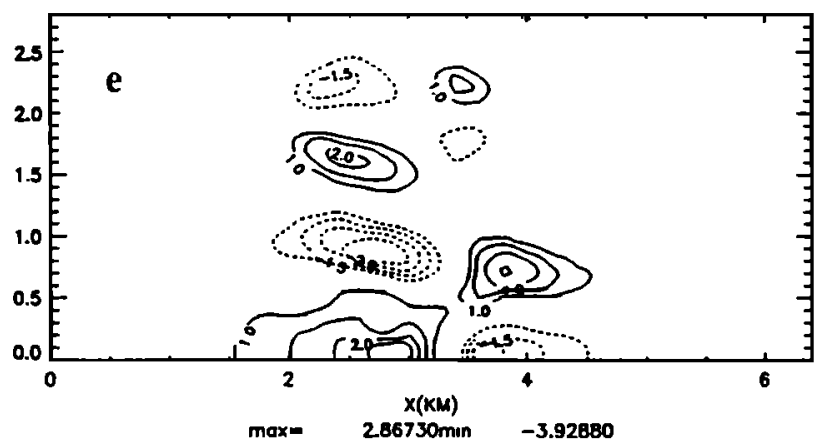

QCW $\mathbf{g} / \mathbf{k g}$

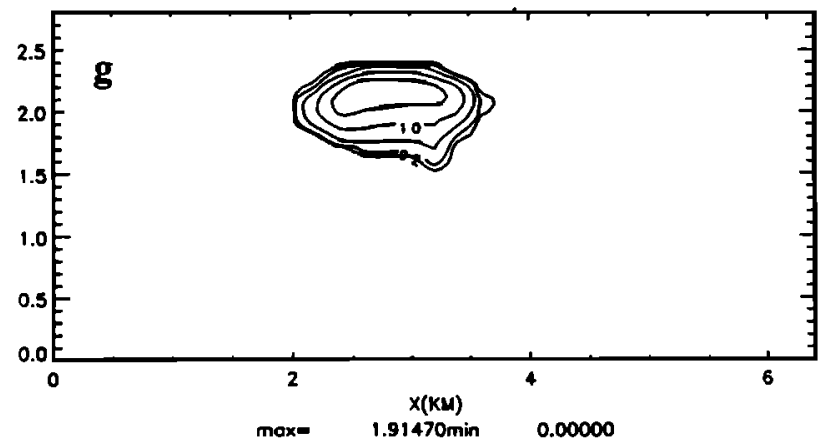

Minutes

W $\mathbf{m} / \mathbf{s}$

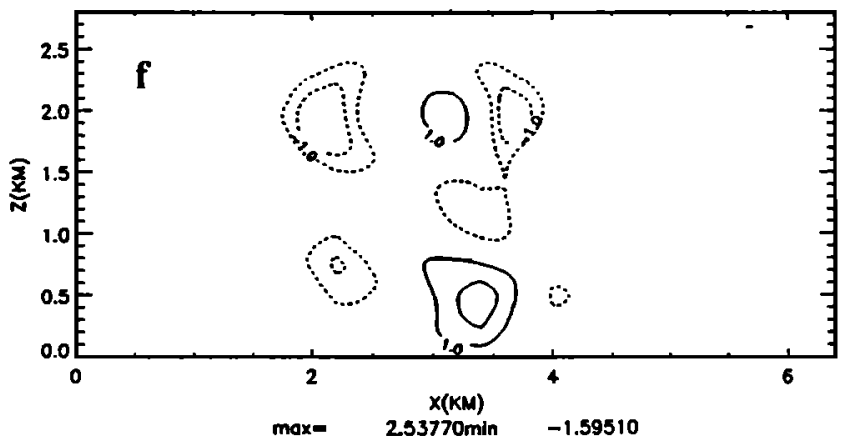

Figure 7. Isolines of horizontal wind, $U$ in meters per second, vertical wind, $W$ in meters per second and cloud liquid water content, QCW in grams per kilogram at different times of the simulation. 
a

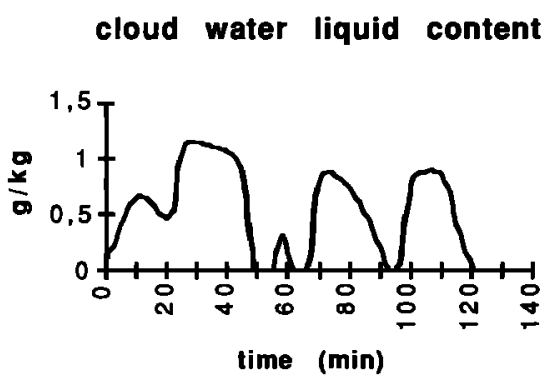

$\mathbf{b}$

vertical wind speed

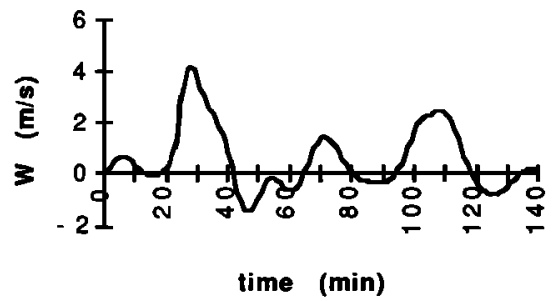

Figure 8. At $1500 \mathrm{~m}$ in center of convection, time evolution during $140 \mathrm{~min}$, of cloud liquid water content (grams per kilogram), of vertical speed (meters per second).

initial value in center of cloud are examined (Figure 12). Curve 1 describes the complete scheme which takes into account all the processes: dynamical, microphysical, and chemical. If the aqueous chemical reactions and the transfer between aqueous and gaseous phases are neglected, the $\mathrm{CO}$ concentration is not modified, because it is not soluble, so that curve 2 is not different from curve 1. For $\mathrm{O}_{3}$ there is a very low increase associated with low $\mathrm{O}_{3}$ solubility and $\mathrm{O}_{3}$ destruction by aqueous chemistry process. These effects remain unimportant. We notice that the increase in $\mathrm{O}_{3}$ follows the liquid water content maximum (condensation), while the decrease of $\mathbf{O}_{3}$ follows the liquid water content minima (evaporation). For curve 3 , we also neglect the dynamical processes, only the gaseous chemical reactions are taken into account like in a box model. In this case, the $\mathrm{CO}$ and $\mathrm{O}_{3}$ concentrations do not vary.
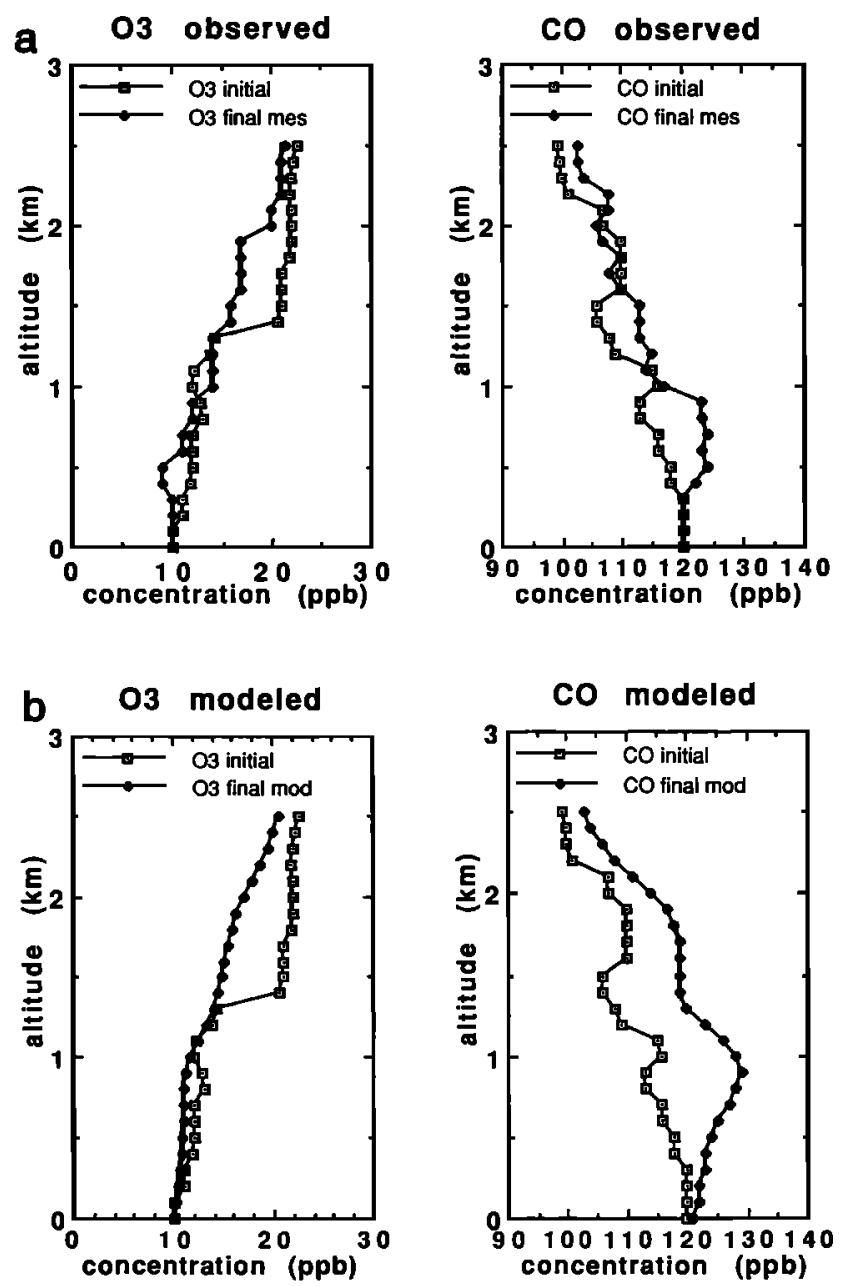

Figure 10. $\mathrm{O}_{3}$ and $\mathrm{CO}$ species mixing ratio profiles (a) obtained during the experiment before and after the presence of cloud and (b) obtained by the simulation after the presence of cloud.

For this kind of cloud (fair-weather cumulus), with low values in $\mathrm{NO}$ and $\mathrm{O}_{3}$ concentration, $\mathrm{CO}$ and $\mathrm{O}_{3}$ behave like inert gases. Photochemistry represents a very low sink for $\mathrm{O}_{3}$ [Scala et al., 1990]. This phenomenon can be explained as follows: first, $\mathrm{CO}$ gas reacts very little with other gases which are in the

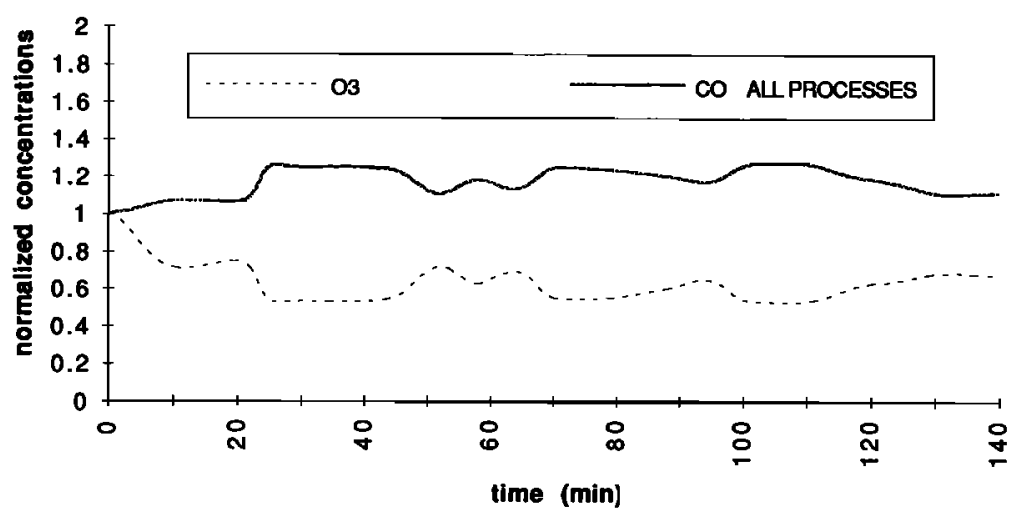

Figure 9. At $1500 \mathrm{~m}$ in center of convection, time evolution during $140 \mathrm{~min}$, of $\mathrm{O}_{3}$ and CO concentration normalized to initial value. 


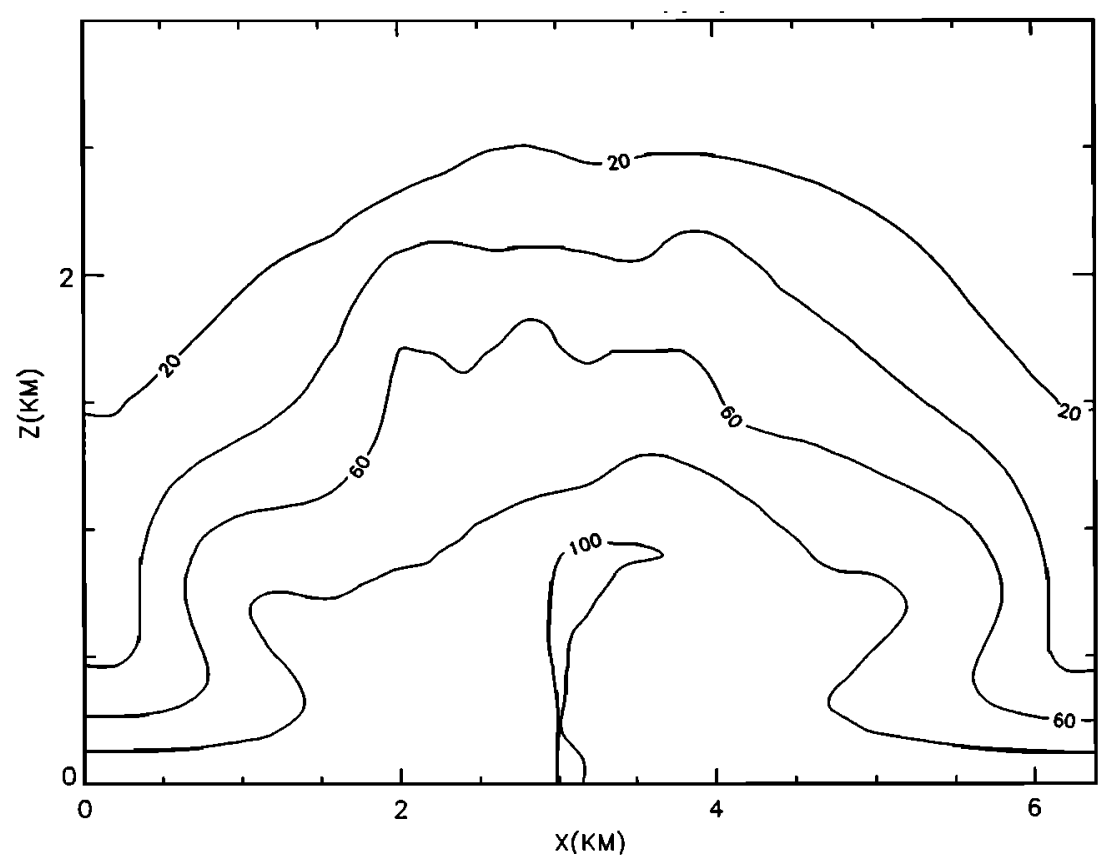

Figure 11. The simulated modification of an inert tracer by cloud transport after $140 \mathrm{~min}$. The initial distribution lies between surface and $500 \mathrm{~m}$.

atmosphere, and moreover, $\mathrm{CO}$ concentration is ten times greater than other gases, including $\mathrm{O}_{3}$. The evolution of $\mathrm{CO}$ and $\mathrm{O}_{3}$ concentration profiles are out of phase: $\mathrm{CO}$ increases with height, while $\mathrm{O}_{3}$ decreases. The vertical cloud transport is the main process driving chemical species redistribution. We see that even fair-weather cumulus perform transport or transformation.

\section{Evaluation of Cumulus Venting Over a Tropical Rain Forest During the Wet Season}

A survey of shallow (fair-weather) cumulus clouds over part of Amazonia yields to evidence of enhanced frequency of occurrence of clouds over zone (in particular along the highway) where the forest had been cleared during the 1988 dry season
[Cutrim et al., 1995]. This may be explained by the great contrast in vegetation cover (deforested areas) that leads to convective motions and therefore shallow cumulus clouds. This is a permanent feature (during wet or dry season).

The boundary layer in wet season over tropical rain forest is not a source for ozone like in a polluted atmosphere but rather a sink [Ritter et al., 1990; Browell et al., 1990]. Between the boundary layer and the free troposphere, weak cumulus can take place and allow the vertical transfer of chemical species such as $\mathrm{CO}$ or $\mathrm{O}_{3}$. These species play a important role in global tropospheric chemistry, and we must estimate the venting in all conditions (here there is shallow convection, above rain forest during the wet season).

In our study, the cloud transforms the fossil layer below $1500 \mathrm{~m}$ during the cloud development and "vents" a part of

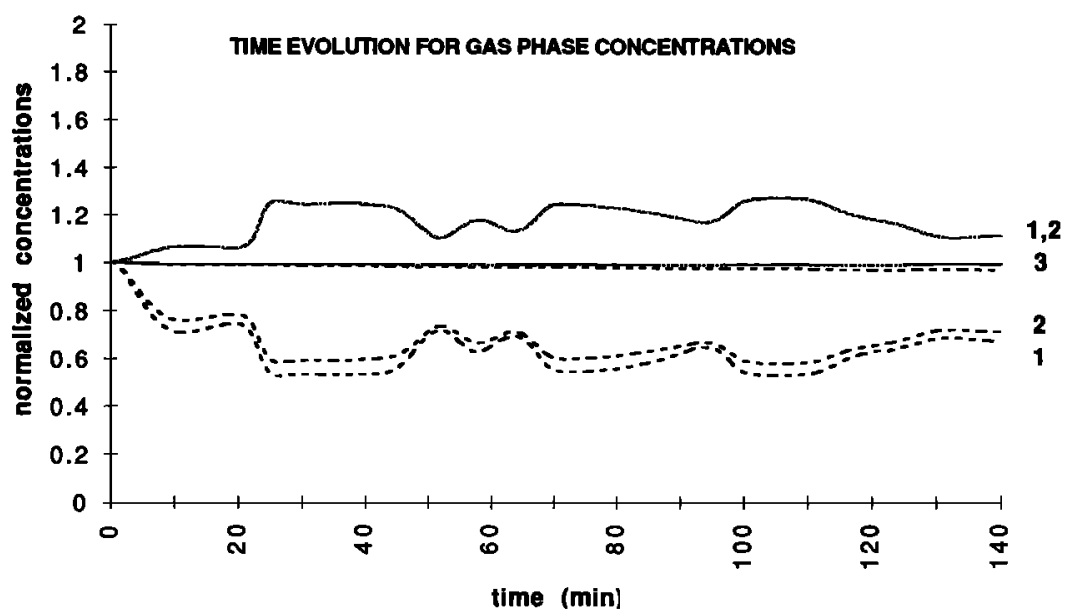

Figure 12. At $1500 \mathrm{~m}$ in center of convection, time evolution during $140 \mathrm{~min}$ of $\mathrm{O}_{3}$ (dotted line) and $\mathrm{CO}$ (solid line) concentration normalized by initial value. Run 1: All the processes (dynamical, gas, and aqueous phases) are taken into account. Run 2: no transfer through the aqueous phase. Run 3: only gas chemistry. 
content above $2000 \mathrm{~m}$ into the free troposphere. We evaluated during the whole simulation the $\mathrm{CO}$ and $\mathrm{O}_{3}$ fluxes between the boundary layer at $1500 \mathrm{~m}$ and the free troposphere toward the cloud top. We have calculated the $\mathrm{CO}$ and $\mathrm{O}_{3}$ net vertical fluxes between these levels. The $\mathrm{CO}$ and $\mathrm{O}_{3}$ upward fluxes are respectively $7.7 \times 10^{23}$ molecules $\mathrm{km}^{-2} \mathrm{~h}^{-1}$ and $1.2 \times 10^{23}$ molecules $\mathrm{km}^{-2} \mathrm{~h}^{-1}$. These amounts are about two hundred times smaller than those obtained for $\mathrm{O}_{3}$ during deep convection (PRESTORM), with high value of NO, which are $7.97 \times$ $10^{11}$ molecules $\mathrm{cm}^{-2} \mathrm{~s}^{-1}$, that is $2.8 \times 10^{25}$ molecules $\mathrm{km}^{-2}$ $\mathrm{h}^{-1}$ [Pickering et al., 1992; Thomson et al., 1994]. In addition, we see that the $\mathrm{CO}$ vertical transport is negligible versus $\mathrm{O}_{3}$ transport.

\section{Conclusions}

We have presented a cloud convection model coupled with a chemical model describing the oxidation chains of $\mathrm{CH}_{4}$ and $\mathrm{CO}$ in presence of $\mathrm{NO}_{x}$ in remote troposphere. A shallow cumulus cloud field has been simulated over tropical rain forest, during the wet season, with low values of $\mathrm{O}_{3}$ and $\mathrm{NO}_{x}$. The case under study represents a local system which includes an active mixing layer from surface to $1000 \mathrm{~m}$ capped by a fossil mixed layer between 1000 and $1500 \mathrm{~m}$, cumulus clouds penetrate into this layer and exchanges between the different layers are examined. We have shown that when vertical motion is strong, the fossil mixed layer and the mixing layer are mixed so that the fossil layer is destroyed. By tracer analysis, we have shown exchanges exist between the lower layer (from surface to $500 \mathrm{~m}$ ) and the free troposphere (above $2000 \mathrm{~m}$ ) across the mixing and fossil layer. After the development of several cycles of cloud cells, when the cloud precipitates, we have two convection cells: the first one from the ground to $1000 \mathrm{~m}$ and the second one from 1300 to $2200 \mathrm{~m}$ where is found a cloud cell. At this time, the exchanges between the two layers are stopped.

The comparison between experimental and modeled $\mathrm{CO}$ and $\mathrm{O}_{3}$ data are in good agreement. The cloud convection smoothes more the $\mathrm{O}_{3}$ vertical profile than the $\mathrm{CO}$ one because $\mathrm{CO}$ is supplied from ground surface and is therefore more concentrated near the surface than in altitude, while the opposite occurs for $\mathrm{O}_{3}$ which is destroyed very weakly within the atmosphere by photochemistry. Sensitivity tests show that the main process driving chemical species redistribution is the dynamical mechanism. The microphysical and chemical processes are of lower importance. We have shown that even small clouds perform transport or transformation in the boundary layer.

The $\mathrm{O}_{3}$ and $\mathrm{CO}$ vertical fluxes between the boundary layer and the free troposphere through the cloud top, are respectively $1.2 \times 10^{23}$ molecules $\mathrm{km}^{-2} \mathrm{~h}^{-1}$ and $7.7 \times 10^{23}$ molecules $\mathrm{km}^{-2} \mathrm{~h}^{-1}$. In tropical region, over rain forest, with low $\mathrm{O}_{3}$ levels, where several cumulus exist every day, the vertical fluxes of some chemical species (like $\mathrm{O}_{3}$ ) cannot be neglected.

Acknowledgments. This study is supported by the "Programme National de Chimie Atmosphérique" of the CNRS. Computer resources were provided by the IDRIS Center (France, project 950187). We thank very gratefully both reviewers for constructive comments and advice, and more particularly the M. Garstang for the helpful information he gave us concerning the ABLE $2 B$ campaign. The authors express their gratitude to N. Chaumerliac for her helpful comments.

\section{References}

Browell, E. V., G. L. Gregory, R. C. Harriss, and V. W. J. H. Kirchhoff, Ozone and aerosol distribution over the Amazon basin during the wet season, J. Geophys. Res., 95, 16,887-16,902, 1990.

Cautenet, S., and B. Lefeivre, Contrasting behavior of gas and aerosol scavenging in convective rain: A numerical and experimental study in the African equatorial forest, J. Geophys. Res., 99, 13,013-13,024, 1994.

Chameides, W. L., and D. D. Davis, The free radical chemistry of cloud droplets and its impact upon the composition of rain, J. Geophys. Res., 87, 4863-4877, 1982.

Chatfield, R. B., and A. C. Delany, Convection links biomass burning to increased tropical ozone: However, models will tend to overpredict $\mathrm{O}_{3}$, J. Geophys. Res., 95, 18,473-18,488, 1990.

Chaumerliac, N., R. Rosset, M. Renard, and E. C. Nickerson, The transport and redistribution of atmospheric gases in regions of frontal rain, J. Atmos. Chem., 14, 43-51, 1989.

Ching, J. K. S., and A. J. Alkezweeny, Tracer study of vertical exchange by cumulus clouds. J. Climatol. Appl. Meteorol., 25, 1702-1711, 1986.

Cutrim, E. M. C., D. W. Martin, and R. Rabin, Enhancement of cumulus clouds over highlands, savannah and deforestation lands in Amazonia, Ann. Geophys., 13, 309, 1995.

Fitzjarrald, D. R., K. E. Moore, O. M. R. Cabral, J. Scolar, A. O. Manzi, and L. D. de Abrau Sa, Daytime turbulent exchange between the Amazon forest and the atmosphere, J. Geophys. Res., 95, 16,825$16,838,1990$.

Garstang, M., et al., Trace gas exchanges and convective transports over the Amazonia rain forest, J. Geophys. Res., 93, 1528-1550, 1988.

Gidel, L. T., Cumulus cloud transport of transient tracers, J. Geophys. Res., 88, 6587-6599, 1983.

Graedel, T. E., and P. J. Crutzen, Atmospheric change. An Earth System Perspective, 446 pp., W. H. Freeman, New York, 1993.

Greco, S. R., M. Swap, M. Garstang, S. Ulanski, M. Shipham, R. C. Harris, R. Talbot, M. O. Andreae, and P. Artaxo, Rainfall and surface kinematic conditions over central Amazonia during ABLE 2B, J. Geophys. Res., 95, 17,001-17,014, 1990.

Greco, S., J. Scala, J. Halverson, H. L. Massie, W. K. Tao, and M. Garstang, Amazon coastal sqall lines, II, Heat and moisture transports, Mon. Weather Rev., 122, 623-635, 1994.

Grégoire, P. J., N. Chaumerliac, and E. C. Nickerson, Impact of cloud dynamics on tropospheric chemistry: Advances in modeling the interactions between microphysical and chemical processes, J. Atmos. Chem., 18, 247-266, 1994.

Harriss, R. C., G. W. Sachse, G. F. Hill, L. O. Wade, and G. L. Gregory, Carbon monoxide over the Amazon basin during the wet season, J. Geophys. Res., 95, 16,927-16,931, 1990.

Hesstvedt, E., O. Hov, and I. S. A. Isaksen, Quasi-steady-state approximations in air pollution modeling: Comparison of two numerical schemes for oxidant prediction, Int. J. Chem. Kinetics, 10, 971-994, 1978.

Houze, R. A., Observed structure of mesoscala convective systems and implications for large-scale heating, Q. J. R. Meteorol. Soc., 487, 425-461, 1989.

Jacob, D. J., Chemistry of $\mathrm{OH}$ in remote clouds and its role in the production of formic acid and peroxymonosulfate, J. Geophys. Res., 91, 9807-9826, 1986.

Jacob, D. J., and S. C. Wofsy, Budgets of reactive nitrogen, hydrocarbons, and ozone over the Amazon forest during the wet season, $J$. Geophys. Res., 95, 16,737-16,754, 1990.

Kessler, E., On the redistribution and continuity of water substance in atmospheric circulation, Meteorol. Monogr., 10(32), 84 pp., 1969.

Lafore, J. P., and M. W. Moncrieff, A numerical investigation of the organisation and interaction of the convective and stratiform regions of tropical squall lines, J. Atmos. Sci., 46, 521-544, 1989.

Lelieveld, J., and P. J. Crutzen, Influences of cloud photochemical processes on tropospheric ozone, Nature, 343, 227-233, 1990.

Lelieveld, J., and P. J. Crutzen, The role of clouds in tropospheric photochemistry. J. Aimos. Chem., 12, 229-267, 1991.

Lyons, W. A., R. H. Calby, and C. S. Keen, The impact of mesoscale convective systems on regional visibility and oxidant distribution during persistent elevated pollution episodes, J. Climatol. Appl. Meteorol., 25, 1518-1531, 1986.

Madronich, S., Photodissociation in the atmosphere, 1, Actinic flux and the effect of ground reflections and clouds, J. Geophys. Res., 92, 9740-9752, 1987. 
Marshall, J. S., and W. M. Palmer, The distribution of raindrops with size, J. Meteorol., 5, 165-166, 1948.

Martin, C. L., D. Fitzjarrald, M. Garstang, A. P. Oliveira, S. Greco, and E. Browell, Structure and growth of the mixing layer over the Amazonian rain forest, J. Geophys. Res., 93, 1361-1375, 1988.

Pickering, K. E., A. M. Thompson, R. R. Dickerson, W. T. Luke, D. P McNamara, J. P. Greenberg, and P. R. Zimmerman: Model calculations of tropospheric ozone production potential following observed convective events, J. Geophys. Res., 95, 14,049-14,062, 1990.

Pickering, K. E., A. M. Thompson, J. R. Scala, W. K. Tao, J. Simpson, and M. Garstang, Photochemical ozone production in tropical squall line convection during NASA Global Tropospheric Experiment/ Amazon Boundary Layer Experiment 2A, J. Geophys. Res., 96, 3099-3114, 1991.

Pickering, K. E., A. M. Thompson, J. R. Scala, W. K. Tao, R. R. Dickerson, and J. Simpson, Free tropospheric ozone production following entrainment of urban plumes into deep convection, $J$. Geophys. Res., 97, 17,985-18,000, 1992.

Preiss, M., R. Maser, H. Franke, W. Jaescke, and J. Graf, Distribution of trace substances inside and outside of clouds, Beitr. Phys. Atmos., 67, 341-351, 1994.

Renard, M., N. Chaumerliac, S. Cautenet, and E. C. Nickerson, Tracer redistribution by clouds in West Africa: Numerical modeling for dry and wet seasons, J. Geophys. Res., 99, 12,873-12,883, 1994.

Ritter, A. J., D. H. Lenschow, J. D. W. Barrick, G. L. Gregory, G. W. Sachse, G. F. Hill, and M. A. Woerner, Airborne flux measurements and budget estmates of traces species over the Amazonian basin during the GTE/ABLE2B Expedition, J. Geophys. Res., 95, 16,875$16,886,1990$
Scala, J. R., Cloud draft structure and trace gas transport, J. Geophys. Res., 95, 17,015-17,030, 1990.

Singh, H. B., D. Herlth, D. O'Hara, L. Salas, A. L. Torres, G. L. Gregory, G. W. Sachse, and J. F. Kasting, Atmospheric peroxyacetyl nitrate measurements over the Brasilian Amazon basin during the wet season: Relationships with nitrogen oxides and ozone, J. Geophys. Res., 95, 16,945-16,954, 1990.

Stockwell, W. R., Communication to the Editor regarding "Lelieveld, J., and P. J. Crutzen, 1991: The role of clouds in tropospheric photochemistry, J. Atmos. Chem., 12, 229-267, 1994.

Talbot, R. W., M. O. Andreae, H. Berresheim, D. J. Jacob, and K. M. Beeker, Sources and sinks of formic, acetic and pyruvic acids over central Amazonia, 2, Wet season, J. Geophys. Res., 95, 16,799$16,811,1990$.

Thompson, A. N., K. E. Pickering, R. R. Dickerson, W. G. Ellis Jr., D. J. Jacob, J. R. Scala, W-K Tao, D. P. McNamara, and J. Simpson, Convective transport over the central United States and its role in regional CO and ozone budgets, J. Geophys. Res., 99, 18,703-18,711, 1994.

P. Brémaud, Laboratoire de Physique Atmosphere, Universíte de l'ile de la Reunion, St. Denis, 95 France.

S. Cautenet and J. Edy, Laboratoire de Meteorologie Physique, Universite Blaise Pascal/CNRS, 24 Avenue des Landais, 63177 Aubière, France.

(Received June 13, 1995; revised May 20, 1996; accepted May 25, 1996.) 